\title{
Covey's Professional Habits in Czech Elementary and Lower Secondary Novice Teachers
}

\section{Andrea Rozkovcová, Magda Nišponská}

\begin{abstract}
The text deals with elementary and lower secondary novice teachers in the Czech Republic, Liberec County, in the context of Covey's professional habits of successful people. The habits were operationalized into measurable factors and expert-driven validation and Cronbach item reliability performed. The correlations confirmed our assumptions of the interrelatedness of the habits on the one hand and on the other hand their uniqueness. The final questionnaire can serve to evaluate the level oo mastering Covey's habits in novice teachers. The adapted version of the questionnaire will prospectively serve as an evaluation tool of effectiveness of educational programmes focused on personal and professional student teacher growth.
\end{abstract}

Key words: Personal and Professional Growth, Elementary Novice teachers, Lower Secondary Novice Teachers, Personal and Professional Habits.

\section{Introduction}

During our long practice educating teacher students in fields of pedagogy and psychology we more and more acknowledge the necessity of educating them differently than predominantly theoretically. We view teacher personality to be of the same importance 
as his or her expertise. Personal growth is a very individual whole-life movement of every person, nevertheless it is directed by some universal principles. When thinking of the growth we have been inspired by Stephen Covey (2006) who studied successful people in historical perspective and recent time. He states there is a specific pattern behind every respectful and wise life embedded in "universal ethic" and in developing inner qualities in which a person believes and which are essential for him or her. Among the qualities Covey mentions integrity, courage, fidelity, responsibility and trustworthiness. Covey noticed that demoralisation and weakness of individuals, groups, organizations and cultures is interrelated with the deviation from essential personal principles, which are, as he believed, the primary conditions of authentic being, and with the shift towards techniques serving the purpose of a plausible being or an expected image. If the techniques serving the latter purpose are not deeply embedded in "character ethic" (Covey, 2006), the effort to impress people or to gain some advantage cannot last long and will be revealed. The truthful being is rooted in character values such as inner meaning, the will to create more permanent values and serve the whole. Techniques and programmes change according to fashion or benevolence of decisionmaking authorities, who are responsible for policies. That does not mean these people understand the fields they decide about properly. There are also important hidden aspects which play an important role in decision-making such as economic or other factors which frequently collide with humanistic and democratic principles and values. Principal values, those which support life, growth, success and happiness of individuals, on the other hand, remain the same and are universal.

For three years we have been reading student essays dealing with the topics: "Teacher (educator) who enriched me" and "Teacher/educator I would not like to be like" (essays are written by teacher students and students of Leisure Studies at Department of Pedagogy and Psychology at Technical university of Liberec). These essays show us how important teachers were and are for students. Students remember with respect and gratefulness the very teachers who lived according to solid principles, believed in meaningful values, were willing to educate them with love and determination even if it was sometimes difficult. Those teachers were interested in their students' inner life and at the same time were able to open to them in a human way, learn from them and grow together. Such teachers live in the students' memories as examples of kindness and humanity. It is these personal qualities which students value more than teacher expertise: interest in the other person, authenticity, modesty, kindness or fairness. The expertise is also important, but it is more subject to change and definitely more often than universal principles.

This text aims at introducing Covey's model of personal and professional growth which stems from the humanism approach to a person. Owing to its comprehensibility and clarity it seems to be a suitable basis on which a subject for teacher study programme can be built. The humanistic and democratic principles are in Czech culture, 
not only in American, perceived as the main and universal societal pillars. It is important to care for these values and transfer them with means of education to following generations as the gift of the greatest value.

Individual Covey's habits were operationalized to gain measurable factors with which we can estimate the level of mastering the habits by novice teachers. In this context we aim at studying the consistence of the model and the degree of similarity of the individual habits.

\section{Theoretical Background}

Important Czech and Slovak authors focus their attention in respect to teaching profession, apart from other serious issues, to professional growth of teachers. For instance Urbánek mentions the importance of teacher's ability to build relationships and the complexity of the profession, in which the teacher adopts various roles and can experience conflict (Urbánek, 2005, p. 23-25). Helus demands "education of transformation" in the sense of personality developing instruction (Helus, 2012, p. 22). This approach requires mature personalities who can practise it. Kohnová speaks about the importance of professional teacher development as a key to the success of educational systems. (Kohnová et al., 2012). Pupala (2006, s. 15) categorizes qualities of a teacher-professional: "... the teacher should be an expert in self-knowledge, in pedagogical relationships, in facilitation of learning and in permanent reflection of their practical activity and selfreflection." Spilková a Vašutová $(2008,2010)$ also significantly contributed to discussion about teacher professional standards and also to the discussion on interconnection of theory and practice during initial teacher education (e. g. Vašutová et al., 2008). Newly Tomková contributes with the principle of isomorphism in teacher education (Tomková, 2015). We also acknowledge the views focusing on curriculum and the quality of teacher education in this respect (Janík, Slavík, 2012). These authors believe that contemporary models of initial teacher education do not sufficiently accentuate didactical preparation of teachers. We try to see the teacher as a complex personality which develops multi-dimensionally. We believe that focusing on supporting character and personal development allows for supporting all dimensions of teacher development (acquiring knowledge and competence, personal development, becoming more professional in didactic transposition and other). We stand the view we cannot divide artificially the personal and professional human growth. They are always both present - if you develop personally it supports professional development and vice versa. The personal as well as the professional growth are based on the ability of reflection and self-reflection and also such behaviours which enable it. Korthagen $(2011,2005)$ introduced the concept of "core reflection" and discussed the importance of reflection and self-reflection in initial teacher education. Covey's model of habits for successful practice (Covey 1989/2006) 
also implicitly demands continuous reflective practice of the individual. Korthagen repeatedly claims that some students do not see any sense in reflecting their practice and he asks why? We have a similar experience with teacher students whose reflective abilities are limited or quite superficial. Such superficial discussions or mere descriptions without deeper reflection and without looking for answers to arising questions are unproductive and unsatisfactory. The openness of students to their own asking can be influenced by some inappropriately built study programmes which force students to participate in many subjects for which they get very few credits. This approach does not allow for asking and looking for answers as it supports quick solutions and quick pass. Students are overloaded with information and mundane tasks and tend to superficial thinking and to the survival strategy. The other important factor of insufficient reflection is the approach of a teacher who does not care for the quality of growth and is content with his or her recent horizon of knowledge.

It is our aim to support questioning, discussion and the reflective approach to experience which students gained throughout their present lives and have been gaining during their initial teacher education. In long-term student teachers should acquire these qualities (questioning, discussion and the reflective approach) to be able to reflect and act in practice when they no longer are under supervision of either teacher educators or expert mentors.

S. Covey (2006) does not speak about reflection explicitly but, when studying his work carefully, reflection lies in the roots of each of the habits. Covey was aware of the importance of reflection in the sense of understanding one's behaviour, thinking, emotions and their implications for the life of an individual. We can say Covey works with self-reflection as the elementary condition of true human growth. Covey's model of personal and professional growth consisting of the seven habits seems to be a useful tool of self-knowledge of the teacher as well as for the reflection of the teacher's interpersonal activity. Could it be a suitable approach for initial teacher education?

In accordance with Korthagen and Covey, we believe, that before being able to teach and educate children, before being able to transfer curricula (in the didactically transposed or the authentic form) the teacher must decide to work on themselves continuously. In Covey's terminology it means the teacher student or the teacher becomes "proactive". We perceive "proactivity" as the key quality enabling personal and professional growth of every teacher in all dimensions of his or her personality. 


\section{The Significance of Reflected Personal Growth for Teacher Profession}

In childhood, the most important forms of learning are imitation, identification and learning from examples (e.g. Říčan, 2005). Quite for this developmental regularity accompanying cognitive and emotional human development it is important that the human who, in the teacher role, comes to educate children was also properly educated. The teacher's behaviour aimed at cultivation of the child should of course be cultivated. The teacher must be able to grow consciously towards universal values and principles and this growth is enabled primarily by self-reflection. Self-reflection helps to compare past and present state of matters, realistically evaluate our own experience, assess contributions and wrong steps and estimate the rate of one's responsibility. Such self-reflection helps to draw conclusions for future conduct. Teacher's ability of self-reflection can be measured through his/her work on personal growth, his/her selfregulation purposefully oriented at mastering such valuable personal qualities which lead the teacher to specifically manifested professional competencies. Teacher's ability to grow can be manifested in his/her ability to create deep and effective relationships with pupils/students and their parents but also with their colleagues. People feel good in the presence of such teachers. People ask the teachers for help freely without being manipulated, asked unpleasant and irrelevant questions, being objected or blamed. Plenty of good teachers mature towards integrity and good character through their own internal effort and through self-reflection. Some teachers live in accordance with the principles without even knowing Covey's model. Nevertheless, theory can help a perceptive and responsive student to find his/her own good direction and a meaning in everything he/she does; it can help to assure oneself in the attitudes and approaches, especially during the time of contradictory experience for which he/she was not prepared at university. This is our attempt to contribute to the discussion on personal and professional teacher growth with an emphasis on values represented not only by Covey but also Rogers, Maslow, Fromm, Satir and other humanistic thinkers.

\section{Covey's Habits of Successful Life}

Now we introduce briefly the habits, except of "synergy", in the succession in which Covey introduces them. Covey claims it is important to develop these habits continuously starting with proactivity (Be proactive), work with vision (Begin with the end in mind), time and priority management (Put first things first). Only when the person touches the innermost powers of the self and develops the first three habits to some level is it possible to cultivate properly the following habits serving the "public victory". They 
are: the win-win approach (Think win-win), emphatic and courageous communication (Seek first to understand, then to be understood). We work here only with the first five habits and the seventh which is the habit of self-renewal (Sharpen the saw), because we consider "synergy" to be rather the final goal than a "habit". In the continuum of cultivating the habits individuals mature to understanding that their person, however unique and important, is a part of community and functions in mutual dependence with others. Synergy is so complex that we excluded it from this research. However, we always bear in mind its importance and use it during initial teacher education.

Proactivity is the way we handle reality. Proactive people can perceive and interpret reality very clearly, they can reflect on themselves, they take into consideration facts and influences. The ability to keep the distance in a situation enables proactive people to act with forethought and consideration. It makes their behaviours maximally human and at the same time effective. Proactivity also enables people to act according to the vision and goals they set (e. g. according to the school vision with which the person identifies. It is important to realize that proactivity is quite the opposite of "reactivity" when people only react to situations without their active participation in regulating their reaction proactively. If we persuade student teachers to become proactive, we are halfway through to their success and success of their pupils. In context with Korthagen's "core reflection" and his conception of the reflective professional (teacher = reflective professional) proactive teachers not only know how to reflect their work and themselves, they also want to do it.

Vision is enabled by the proactive approach. It means people can see the situation and the potential for change. Such people take responsibility for creating their own goals and understand their role of active creators of their own personal and professional lives. The vision includes expressed meaning of action, a clear image of the future and a certain possibility of change. Thanks to vision teachers can start to plan steps and strategies to fulfil the goal/vision. Vision enables the teacher to plan concrete steps of action towards fulfilling it. With regard to the need of changing the Czech school system (and the system seems quite resistant to change for many reasons), the vision in the mind and heart of every teacher is of greatest importance. Every school should have their own vision (perhaps in the form of the School Educational Programme). Teachers who perceive the job as their mission or calling need the vision. The vision is also a very important part of the strategical developmental school plan. Teachers who understand the school vision and agree with it tend to be much more engaged.

Self-organization in Time - if we have our vision or share it with our team, e.g. the teacher faculty, we need organizational skills to realize it. Organization according to disposable time and priorities in Covey's model includes personal as well as professional life planning. This kind of planning works with values and priorities and it helps to focus in our behaviour towards our vision. It is a higher level of time-management skills. 
Problem-solving "win-win" - it means that the effective and human problem solving is based on looking for solutions suitable for all parties. It is a way of keeping our relationships harmonious showing respect for others - their time, individual character and needs. We do the same for ourselves though, as it is necessary for personal integrity and self-renewal. If the solution is not "win-win" for both sides, it is better not to "make the deal". There is no manipulating, the relationships can stay correct and this fact can contribute to finding a solution in the future when something changes (e. g. legislation, financing etc.).

Communication is essential for problem-solving, realization of our visions and for relationships. To become a peaceful, reasonable, human and constructive communicator can be difficult for some individuals (false communication patterns, pride and immodesty, lack of experience etc.). Our variable "communication" includes two components - courage and clarity. Courageous communication is important if we want to explain our point of view and persuade someone of our ideas. Clarity is important for explanation, elucidation and instruction.

Self-renewal is a habit of balancing giving and taking. We consciously restore energy for further giving. Self-renewal is more than pure "psycho-hygiene" as self-renewal often brings new ideas, visions and the personality growth. Self-renewal activities are individual and unique and it is only essential to help people cultivate the habit and support their further learning and cultivation. The aim of this habit is not only finding activities for "psycho-hygiene" but to understand how much we do for our self-renewal just with acting in accordance with the other above-mentioned habits.

\section{Research}

\section{Aims}

In our study we set three aims:

1. To create a questionnaire for measuring the level of the Covey's habits internalization and manifestation in novice teachers including the content validation of the instrument

2. To administer the questionnaire to novice teachers in Liberec County and to verify its reliability using item analysis.

3. To find out interrelations among variables (habits) using correlation analysis.

\section{The Research Instrument}

The first aim of the study was to define and operationalize Covey's habits to create measurable factors in the form of a questionnaire "CHT" (Covey's Habits for Teachers). We followed standard steps required in the process of operationalization, from defining variables, formulating items through expert-driven content validation. Five experts 
with good knowledge of Covey's work contributed to the final version of the instrument. In the scale-construction we were inspired by Bandura's "Teacher Self-Efficacy Scale" (Bandura 2006), as we came to a conclusion that Covey's habits can be viewed as complex self-regulatory strategies (Zimmerman et al., 1992, s. 665). The items in Bandura's questionnaire (2006) begin with "How much can you...?" In our questionnaire we used the words "To what extent can you/do you/are you..." etc. because we wanted to soften the pressure on respondents answering sensitive questions and also to identify more precisely, how they perceive their inner dispositions to act and not only their final outcomes. The final questionnaire consists of 78 7-point Likert items on which respondents had to specify the level of their agreement with each statement.

The final questionnaire was administered to respondents (sample specified below) and gathered data were analysed using Cronbach alpha statistics to estimate the internal consistency of statements. All the scales displayed the Cronbach alpha $>0,80$, only the Communication scale $a=0,76$. We supposed that the scale might not be unidimensional, so we used factor analysis (PCA with Varimax normalized rotation) which revealed two separate communication subscales (factors with eigenvalue $\lambda>1$ ) with Cronbach alpha level above 0,8. These subscales were labelled as "Courageous communication" and "Comprehensible communication". Table 1 shows Covey's habits with brief definitions and items used.

\section{Table 1}

\section{Operationalized Habits; CHT-questionnaire}

\begin{tabular}{l|l|}
\hline PROACTIVITY & Cronbach a: 0,82 \\
Definition: To act actively in accordance with the values and respect towards people and situations.
\end{tabular}

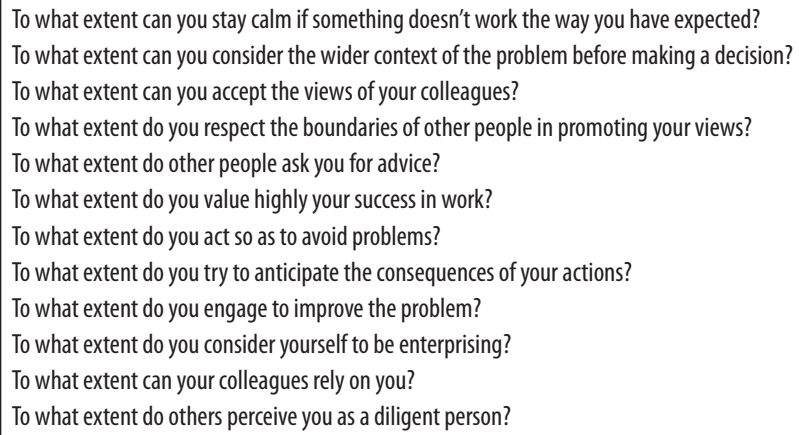


VISION

Definition: All I do in my life, I do it with the idea of the final output.

To what extent do you consider what your student will become in a result of your influence?

To what extent do you set your career goals reaching beyond one year plan?

To what extent do you have a clear idea of your future career development?

To what extent do you think about what improvements can be made in your profession?

To what extent can you redirect yourself towards desired outcomes under changing conditions?

To what extent do you have clearly defined goals?

To what extent do you work systematically to achieve your goals?

To what extent do you keep working hard to achieve your goals?

To what extent are you successful in achieving your goals?

To what extent are you living your life according to meaningful values?

To what extent do you consider your thinking innovative?

To what extent do you plan educational activities for your professional development?

To what extent do you take part in educational activities for your professional development?

SELF-MANAGEMENT IN TIME

Definition: I always put important things at the first place.

To what extent do you complete your professional duties according to headmaster's demands?

To what extent can you finish your tasks before appointed time?

To what extent are you able to effectively organize your work?

To what extent do you attempt to reach excellence in everything you do?

To what extent do you find enough time for important professional matters?

To what extent do you waste time before you get started?

To what extent do you get into situations of not having enough time to fulfill your professional duties?

To what extent do you attempt to fulfill your tasks with utmost conscientiousness?

To what extent do you consider yourself as a well-organized person?

WIN-WIN PROBLEM SOLVING

Definition: I try to come up with the best possible solution for all involved participants.

To what extent can you accept the compromise while solving problem situations with others?

To what extent can you alone find solutions when solving a problem situation in a team?

To what extent do you believe that more people can come up with a better solution?

To what extent are you a team player?

To what extent do you have the patience to look for mutual solutions?

To what extent do you spend time with colleagues to find solutions good for everyone?

To what extent do you approach problem solving looking for benefits for everyone?

To what extent can you influence other people to cooperate? 
COMMUNICATION

Definition: I can clearly and courageously communicate my ideas.

ComA - courageous communication and self-assertiveness

To what extent can you stand up for your ideas although the others disagree?

To what extent do you have the courage to argue?

To what extent can you win the trust of others?

ComB - comprehensible communication

To what extent do you feel other people don't listen to you enough?

To what extent can you express your views in a clear and comprehensive way?

To what extent do people appreciate your ability to clearly communicate complex ideas?

SELF-RENEWAL

Definition: I keep caring for myself to renew my energy.

To what extent can you separate your professional and personal life?

To what extent can you find enough time for your hobbies?

To what extent do you praise yourself for your success?

To what extent do you reward yourself for your success?

To what extent can you relax?

To what extent do you know which activities renew your energy?

To what extent do you engage in a regular physical activity?

To what extent do you eat regularly?

To what extent do you eat healthy foods?

To what extent do you find time for friends?

To what extent do you meet with your family at the dinner table?

To what extent do you love your life?

\section{Sample}

Questionnaires were administered online. Headmasters of basic schools (ISCED levels 1 and 2) were sent an email asking them to resend the questionnaire to their novice teachers. The criteria of sample selection were: novice teachers with teaching practice up to 5 years, levels of education ISCED 1 and 2 from schools in Liberec County. Gained sample can be described as nonprobability purposive sample with high homogeneity. $30 \%$, of respondents completed and returned questionnaires, which counts for 50 cases of approximately 150 novice teachers in Liberec County (approximation made according to information collected from authorities in the County). 


\section{Results and Discussion}

This chapter introduces results of the correlation analysis. The findings of significant correlations support our assumptions of deeper psychological interconnection among individual habits. We can reason that the constructs are independent but at the same time related. The majority of correlations are significant at alfa $<0,01$ or alfa $<0,05$ and at the same time Spearman coefficient $r$ does not exceed the value of 0,75.

Table 2

Spearman correlations ( $r$ ); statistical significance $p<0.01^{* *}, p<0.05^{*}$

\begin{tabular}{|l|l|l|l|l|l|l|l|}
\hline Variable & Pro & Vision & Time & Win & ComA & ComB & Self \\
\hline Pro & 1.00 & & & & & & \\
\hline Vision & $0.59^{* *}$ & 1.00 & & & & & \\
\hline Time & $0.52^{* *}$ & $\mathbf{0 . 4 3 ^ { * * }}$ & 1.00 & & & & \\
\hline Win & $0.59^{* *}$ & $\mathbf{0 . 4 2 ^ { * * }}$ & $\mathbf{0 . 3 4 ^ { * }}$ & 1.00 & & & \\
\hline ComA & 0.25 & $\mathbf{0 . 4 3 ^ { * * }}$ & 0.12 & 0.21 & 1.00 & & \\
\hline ComB & $\mathbf{0 . 2 7 ^ { * }}$ & 0.20 & 0.22 & $0.46^{* *}$ & $0.29^{*}$ & 1.00 & \\
\hline Self & $\mathbf{0 . 4 9 ^ { * * }}$ & 0.15 & 0.25 & $0.38^{* *}$ & $0.27^{*}$ & 0.22 & 1.00 \\
\hline
\end{tabular}

Variables: Pro - proactivity, Vision, Time - Managing oneself in time, Win - attitude of solving problems in "win-win" manner, ComA - courageous communication, ComB - comprehensible communication, Self - self-renewal.

Our sample shows correlations of proactivity with vision, self-management in time, win-win problem solving and self-renewal. There are weaker correlations with communication. There, courageous communication correlates with vision and comprehensible communication correlates with the win-win problem solving attitude. We can also state that if a teacher in our sample has higher rate in one quality, he/she will dispose of higher rate in the other measured qualities.

These final figures correspond with Covey's assumption of the interconnectedness of the habits and their irreplaceability in the model. It is necessary to remember that Covey's model is a result of his long-term practical experience with resolving various problems of successful and unsuccessful people and on his sharp intuition, deep psychological knowledge and observing professionally successful people. Our results confirm his logical considerations. We want to see, if there would be similar results in a bigger sample which we want to verify in a whole-country research. 


\section{Conclusion}

We focused on Covey's model with persuasion of its usefulness for personal and professional growth as well as enhancing life and work quality of (not only) Czech teachers. This model can, due to its complexity, serve as a base for orienting teacher students towards practical development of the habits and with them, and thanks to them, towards acquiring specific teacher qualities (knowledge, skills, competences, contextual understanding, etc.) Covey prepared a collection of activities and exercises which we can, directly or in a modified form, use during initial teacher education. We think we can relate the model to recognized theories, such as Erikson's theory of development in social contexts (Erikson, c2015), Bandura's Social learning theory (Bandura, 1970) and Self-efficacy (Bandura, 1997), Roger's person-oriented approach and others (Rogers, 1980/2014). Future theorizing or research design can be based on the named theories and their relations with Covey's habits. Last but not least, Covey's model is open to personal and professional diversity - subject orientation, level of education, uniqueness of teacher's personality, etc.

The questionnaire which we used can serve two purposes. The research can be repeated to support or reject the findings and, if appropriately modified for teacher students, it can measure effectiveness of educational programmes aiming at teacher student personal and professional growth.

We are aware of internal and external limitations which, to some extent, determine a human. These determinants will always be present, but there is hope it the phrase "to some extent". Student teachers will probably not be able to acquire all the habits to a very high level of practice very early in their career. It is not to be expected that all novice teachers will influence powerfully and early in their career the senior teachers or decision-making bodies. Nevertheless, we believe that if teacher students work with the model and practice the habits, it will be beneficial for them and especially for their future pupils/students. Teacher's professional growth can accelerate and, as we believe, teachers will have a powerful tool to educate their pupils/students - their mature and ever developing self.

\section{References}

Bandura, A. (2006). Guide for Constructing Self-Efficacy Scales. In Pajares, F., \& Urdan, T. C. (2006). Self-efficacy beliefs of adolescents. Greenwich, Conn: IAP - Information Age Pub.

Bandura, A., \& Walters, R. H. (1970). Social learning and personality development. London: Holt, Rinehart and Winston.

Bandura, A. (1997). Self-efficacy: The exercise of control. New York: W. H. Freeman.

Covey, S. R. (2006). 7 návyků skutečně efektivních lidí. Praha: Management Press.

Erikson, E. H. (2015). Životní cyklus rozšířený a dokončený: devět věků člověka. Praha: Portál. 
Helus, Z. (2012). Perspektivy učitelství. Praha: UK, Pedagogická fakulta.

Kohnová, J. a kol. (2012). Profesní rozvoj učitelů a cíle školního vzdělávání. Praha: UK, Pedagogická fakulta.

Korthagen, F. (2011). Jak spojit praxi s teorií: didaktika realistického vzdělávání učitelů. Brno: Paido.

Korthagen, F. \& Vasalos, A. (2005). Levels in reflection: core reflection as a means to enhance professional growth. Teachers and Teaching: Theory and Practice. 2005-2-1, 11(1): 47-71. [retrieved from http://www.tandfonline.com/doi/abs/10.1080/1354060042000337093]

Pupala, B. (2006). Profesijný rozvoj učitela. Prešov: ROKUS.

Rogers, C. R. (2014). Způsob bytí: klíčová témata humanistické psychologie z pohledu jejího zakladatele. Praha: Portál.

Říčan, P. (2006) Cesta životem: [vývojová psychologie]: přepracované vydání. Praha: Portál.

Slavík, J. \& Janík, T. (2012). Kvalita výuky: obsahově zaměřený přístup ke studiu vyučování a učení. Pedagogika, 3, 262-286.

Spilková, V., \& Vašutová, J. (2008). Učitelská profese v měnících se požadavcích na vzdělávání. Praha: UK, Pedagogická fakulta.

Spilková, V., \& Tomková, A. (2010). Kvalita učitele a profesní standard. Praha: Univerzita Karlova, Pedagogická fakulta.

Tomková, A. (2015). Princip izomorfismu v učitelské přípravě. Pedagogika, 65, 1, 75-81.

Urbánek, P. (2005). Vybrané problémy učitelské profese: aktuální analýza. Liberec: TUL, Fakulta pedagogická.

Vašutová, J. et al., (2008). Vzděláváme budoucí učitele. Praha: Portál.

Zimmerman, B. J., Bandura, A. \& Martinez-Pons, M. (1992). Self-Motivation for Academic Attainment: The Role of Self-Efficacy Beliefs and Personal Goal Setting. American Educational Research Journal. 29(3): 663-676. [retrieved from: http://aer.sagepub.com/cgi/doi/10.3102/00028312029003663]

\section{Contact:}

Mgr. Andrea Rozkovcová, Ph.D.

PhDr. Magda Nišponská, Ph.D.

Technická univerzita v Liberci

Katedra pedagogiky a psychologie FP TUL

Univerzitní náměstí 1410/1, 46117 Liberec

E-mail: andrea.rozkovcova@tul.cz

magda.nisponska@tul.cz 